\title{
КРИМІНАЛЬНО-ПРАВОВЕ ЗАБЕЗПЕЧЕННЯ ОХОРОНИ ПОРЯДКУ ВИКОНАННЯ СУДОВОГО РІШЕННЯ: ОКРЕМІ ТЕОРЕТИЧНІ АСПЕКТИ
}

Юсубов К. В.

У науковій статті досліджено й узагальнено теоретико-правовий доробок наукових досліджень щодо системи кримінально-правових засобів у межах кримінально-правової охорони порядку виконання судового рішення. Проаналізовано дискусійні та проблемні питання щодо відсутності єдиної позиції щодо з'ясування об'єктивних та суб'єктивних ознак складу злочину невиконання судового рішення; неврахування позитивного досвіду держав Європейського Союзу щодо встановлення відповідальності за невиконання судового рішення та інше.

Ключові слова: кримінальна відповідальність, судове рішення, невиконання судового рішення, кримінально-правова охорона правосуддя, злочини проти правосуддя, обов'язковість виконання судового рішення.

В научной статье исследовано и обобщено теоретико-правовое наследия научных исследований по системе уголовно-правовых средств в рамках уголовно-правовой охраны порядка исполнения судебного решения. Проанализированы дискуссионные и проблемные вопросы относительно отсутствия единой позиции по выяснению объективных и субъективных признаков состава преступления невыполнение судебного решения; неучет положительного опыта государств Европейского Союза относительно установления ответственности за неисполнение судебного решения и другое.

Ключевые слова: уголовная ответственность, судебное решение, неисполнение судебного решения, уголовно-правовая охрана правосудия, преступления против правосудия, обязательность исполнения судебного решения.

Yusubov K. V. Criminal and legal enforcement of protection of the procedure of enforcement of a judgment: certain theoretical aspects

The article summarizes the theoretical and legal development of scientific research on the system of criminal remedies in the framework of criminal law protection of the execution of court decision. Discussion and problematic issues concerning the lack of a common position on the clarification of objective and subjective signs of the crime of non-execution of court decision are analyzed; disregard for the positive experience of the European Union in establishing liability for non-compliance with court decision, etc. We came to the conclusion about a significant degree of scientific development of non-enforcement of court decisions in criminal law. In addition, some of the provisions expressed in legal science are debatable, or require further study over time, changes in legislation or criminal law policy of the state. In particular, first of all, it is a question of what crimes concern those which encroach on the order of execution of court decision, about a subject of the crime provided by Art. 382 of the Criminal Code, namely the affiliation of those court decisions that are not the subject of coercive enforcement, the attribution of certain acts related to non-execution of court decisions to criminal offenses, determining the form of guilt in crimes that encroach on the execution of court decision. Also in the context of the systemic nature of the problem of non-enforcement of court decisions, there are questions about its intentional non-compliance with the opinion of the Constitutional Court of Ukraine on the validity of criminal liability for non-compliance with ECtHR and Constitutional Court decisions, as well as intentional non-compliance with the Constitutional Court. Further research is needed to identify the circumstances that could be grounds for exemption from criminal liability for non-compliance with court decision and the expediency of enshrining the Criminal Code of this type of exemption from criminal liability.

Key words: criminal liability, court decision, non-execution of court decision, criminal-legal protection of justice, crimes against justice, binding execution of a court decision.

Постановка проблеми та їі актуальність. Запровадження кримінально-правової охорони будь-якого суспільного явища має бути обґрунтовано системою чинників, які підлягають урахуванню під час установлення кримінально-правової заборони утримуватись від певної дії. Зазначені чинники є динамічними та такими, що перебувають у безпосередньому зв'язку з різними аспектами не лише функціонування держави, але й суспільного розвитку. Водночас у будь-якому разі невиконання судового рішення $\epsilon$ суспільно шкідливим у контексті небезпечності як для суспільства, так і для особи або групи осіб. Важливим $є$ усвідомлення потреб суспільства у кримінально-правовій охороні суспільних відносин, які мають загальноціннісне значення. Крім цього, деякі положення, висловлені в юридичній науці, $\epsilon$ дискусійними, або такими, що потребують подальшого вивчення з урахуванням плину часу, змінами в законодавстві або у кримінально-правовій політиці держави. Викладене зумовлює актуальність теми дослідження чинників соціальної обумовленості кримінально-правової охорони порядку виконання судових рішень.

Аналіз останніх досліджень і публікацій. Кримінально-правова охорона порядку виконання судового рішення характеризується значним ступенем наукової розробки. Зокрема, іï різні складники становили предмет дисертаційних досліджень Г.І. Богонюк, М.О. Букач, В.В. Налуцишина, О.Р. Романишин. Зазначені дисертаційні дослідження були здійснені протягом 2012-2019 років у межах кримінально-правової охорони порядку виконання судового рішення: кримінально-правові норми, закріплені у статтях 382, 389-390-1 КК України, у форматі як кримінально-правової характеристики, так і порівняльно-правового дослідження, а також методів кримінально-правової політики, а саме в контексті криміналізації/декриміналізації та пеналізації/депеналізації та чинників, котрі їх зумовлюють.

Так, О.Р. Романишин [1] здійснено дослідження кримінально-правового забезпечення охорони порядку виконання судових рішень. Зокрема, в дослідженні узагальнено складники кримінально-правового забез- 
печення охорони порядку виконання судових рішень як системи, котрі полягають, зокрема, в наявності загальної та спеціальних норм, диференціація кримінальної відповідальності залежно від виду судового рішення (проміжного та остаточного), залежно від невиконання судового рішення у кримінальному провадженні за видами покарань, залежно від невиконання вимог правового режиму відбування покарання. На думку дослідниці, невирішеними та дискусійними питаннями щодо кримінально-правового забезпечення охорони порядку виконання судових рішень в Україні $\epsilon$, зокрема, такі: віднесення окремих злочинів, які посягають на відповідний порядок, до кримінальних проступків; визначення спеціальних механізмів звільнення від кримінальної відповідальності за злочини, що полягають у невиконанні судових рішень; застосування заходів кримінально-правового характеру за їх вчинення тощо [1, с. 7].

Дисертаційне дослідження В.В. Налуцишина («Кримінальна відповідальність за невиконання судового рішення за законодавством України та держав Європейського Союзу», 2019) було присвячено кримінально-правовій характеристиці невиконання судового рішення за законодавством України та держав Європейського Союзу. Зокрема, науковцем у контексті різних концепцій визначення поняття об'єктивного боку складу злочину проаналізовано ознаки об'єктивного боку складу злочину, передбаченого ст. 382 КК України «Невиконання судового рішення», та об'єктивну сторону кримінально-караних діянь за невиконання судового рішення за законодавством держав ЄC, а також визначено способи скоєння злочину невиконання судового рішення. У дослідженні акцентовано увагу, що, на відміну від норми, яка передбачає відповідальність за невиконання судового рішення в Україні, в законодавстві держав ЄС урізноманітнено способи вчинення аналогічних злочинів, а досліджувані норми мають формальний характер.

Метою статті $\epsilon$ узагальнення теоретико-правового доробку наукових досліджень щодо системи кримінально-правових засобів у межах кримінально-правової охорони порядку виконання судового рішення.

Виклад основного матеріалу. У науці немає єдиного підходу до визначення поняття кримінально-правової охорони. В.В. Кузнецов, наводить три основні підходи до визначення цього поняття:

1) ототожнення кримінально-правової охорони з механізмом правового регулювання суспільних відносин (Н.О. Гуторова, О.О. Дудоров);

2) обумовленість кримінально-правової охорони охоронною функцією кримінального права (В. К. Матвійчук, Т. А. Павленко);

3) розуміння кримінально-правової охорони як захисту суспільних відносин (І.М. Копотун) [2, с. 107].

У зазначеному дослідженні ми спираємось на розуміння кримінально-правової охорони, сформульоване В.В. Кузнецовим, як системи кримінально-правових засобів, до котрих включені кримінально-правові норми та методи кримінально-правової політики, за допомогою яких нормативність права переводиться в упорядкованість суспільних відносин.

Серед проблемних питань кримінально-правової охорони порядку виконання судового рішення, котрі, на думку В.В. Налуцишина, необхідно виділити такі:
1) відсутність єдиної позиції щодо з'ясування об'єктивних та суб'єктивних ознак складу злочину невиконання судового рішення;

2) неврахування позитивного досвіду держав Європейського Союзу щодо встановлення відповідальності за невиконання судового рішення;

3) відсутність заохочувальних норм, які, за визначених законом умов, звільняли від кримінальної відповідальності за невиконання судового рішення [3, с. 5].

Предмет дослідження М.О. Букач становила кримінальна відповідальність за невиконання судового рішення («Кримінальна відповідальність за невиконання судового рішення», 2017). Зокрема, дослідницею обґрунтовано доцільність віднесення невиконання судового рішення через необережність до кримінальних проступків як проміжного кримінального правопорушення між злочином, передбаченим ч. 1 ст. 382 КК України, й подібними до нього адміністративними правопорушеннями (ст. ст. 185-6, 186-5 КУпАП) та розроблено перелік заходів виховного характеру, котрі мають бути застосовані під час звільнення від кримінальної відповідальності у зв'язку з передачею на поруки (ст. 47 КК України) особи, яка вчинила злочин, передбачений частиною першою або другою ст. 382 КК України. Крім цього, М.О. Букач досліджено доктринальні підходи щодо визначення переліку судових рішень, які можуть визнаватися предметом злочину, передбаченого ст. 382 КК України:

1) рішення, ухвала, постанова, вирок, судовий наказ, постановлені судами України, передбаченими Законом України «Про судоустрій і статус суддів»;

2) рішення третейського суду, щодо якого компетентним судом України постановлено ухвалу про видачу виконавчого документа на примусове виконання рішення третейського суду;

3) рішення іноземного суду (суду іноземної держави; інших компетентних органів іноземних держав, до компетенції яких належить розгляд цивільних чи господарських справ; іноземних чи міжнародних арбітражів), дозвіл на примусове виконання якого на території України надано ухвалою компетентного суду; ухвала про виконання вироку суду іноземної держави, міжнародних судових установ;

4) рішення ЄСПЛ. Також науковицею було обґрунтовано доцільність визнання факту вчинення злочину, передбаченого ст. 382 КК, підставою для застосування до юридичних осіб заходів кримінально-правового характеру, зокрема, аргументовано висновок, що безпосередньо до юридичних осіб, указаних у ч. 2 ст. 96-4 КК України, доцільно застосовувати виключно штраф як захід кримінально-правового характеру.

Відповідно до п. 4 Стратегії реформування судоустрою, судочинства та суміжних правових інститутів на 2015-2020 роки, затвердженої Указом Президента України від 20 травня 2015 року № 276/2015 одним з основних напрямів реформування судочинства та правових інститутів визнано реорганізацію системи виконання судових рішень та підвищення ефективності виконавчого провадження. У п. 3, аналізуючи нинішній стан правосуддя, автори Стратегії реформування судоустрою констатували невиконання системою правосуддя поставлених перед нею завдань на належному рівні, зокрема наявність істотних проблем у системі виконання судових рішень, наприклад, таких, як: 
1) гранично низька частка фактичного виконання судових рішень;

2) відсутність ефективної системи мотивації державних виконавців;

3) системні недоліки у взаємодії державних виконавців з іншими державними та недержавними установами у виконанні остаточних рішень національних судів, винесених проти держави та підпорядкованих їй суб'єктів, а також відсутності ефективного засобу юридичного захисту [4]. Цього ж дня Комітет міністрів P€ ухвалив тимчасову резолюцію (CM/ResDH(2008)1), у якій висловив «особливу занепокоєність» недостатністю зусиль, докладених Україною «щоб подолати структурну проблему невиконання рішень національних судів» та переконливо рекомендував державним органам України визначити як особливий політичний пріоритет дотримання своїх зобов'язань за Конвенцією із прав людини та виконання рішень ЄСПЛ, щоб забезпечити повне і вчасне виконання рішень національних судів. Також Комітет міністрів РЄ рекомендував органам влади розглянути можливість запровадження тимчасових заходів на період, протягом якого прийматимуться відповідні закони, серед яких - забезпечити ефективну реалізацію положень про відповідальність посадових осіб за невиконання рішень.

Серед проблемних питань, пов'язаних із кримінально-правовою охороною порядку виконання судового рішення, М.О. Букач підкреслює доцільність застосування до юридичної особи заходів кримінально-правового характеру за умови вчинення їі вповноваженою особою злочину, передбаченого ст. 382 КК, доцільність звільнення суб' єкта невиконання судового рішення від відбування покарання на підставі закону України про амністію, від призначення покарання (ч.ч. 4 і 5 ст. 74, ст. 86 КК), від кримінальної відповідальності за нормами, передбаченими ст.ст. 47-49 КК України, а також звільнення юридичної особи від застосування заходів кримінально-правового характеру за умови визнання факту вчинення злочину, передбаченого ст. 382 КК України [5, с. 6]. Дослідження кримінально правової характеристики невиконання судового рішення здійснено Г.І. Богонюк («Кримінально-правова характеристика невиконання судового рішення», 2016). Зокрема, дослідницею запропоновано перелік судових рішень, котрі можуть визнаватись предметом злочину, передбаченого ст. 382 КК. Причому, на думку Г.І. Богонюк, рішення про визнання права, конститутивні рішення, а також рішення про відмову в задоволенні позову не можуть бути предметом злочину, передбаченого ст. 382 КК України, оскільки не $\epsilon$ предметом примусових виконавчих правовідносин. Також науковиця обґрунтувала невідповідність між санкціями статей Особливої частини КК України, які передбачають кримінальну відповідальність за невиконання судового рішення, щодо дотримання співвідношення ступенів суворості окремих видів покарань, що визначені в санкціях простих та кваліфікованих складів злочинів, передбачених ч. 1 та ч. 2 ст. 382; ч. 2 та ч. 3 ст. 382; ч. 1 та ч. 2 ст. 388 КК. До проблемних питань Г.І. Богонюк відносить відсутність єдиного вирішення питань щодо з'ясування об'єктивних та суб'єктивних ознак складів злочинів, які полягають у невиконанні судового рішення; розмежуванні аналізованих посягань від суміжних складів злочинів або злочинів, передбаче- них конкуруючими кримінально-правовими нормами; призначення покарання за невиконання судового рішення [6, с. 5].

Кримінально-правова охорона порядку виконання судових рішень досліджувалась В.А. Головчуком («Кримінально-правова охорона порядку виконання судових рішень», 2012). Так, дослідником сформульовано поняття «порядок виконання судових рішень» та «кримінально-правова охорона порядку виконання судових рішень», здійснено систематизацію чинників соціальної обумовленості кримінально-правової охорони порядку виконання судових рішень та виділено окрему категорію злочинів проти правосуддя, котрі посягають на порядок виконання судових рішень. Також дослідником розроблено критерії та ознаки, на підставі яких проводиться відмежування злочинів, що посягають на порядок виконання судових рішень, від суміжних злочинів: ухилення від сплати аліментів на утримання дітей; ухилення від сплати коштів на утримання непрацездатних батьків; службової недбалості; незаконних дій щодо майна, яке підлягає конфіскації; ухилення від покарання, не пов'язаного з позбавленням волі та ухилення від відбування покарання у вигляді обмеження волі та у вигляді позбавлення волі [7, с. 9].

Також у дисертаційних дослідженнях науковців були висвітлені питання, пов'язані з невиконанням рішення суду у кримінальному провадженні. Зокрема, в дослідженні О.В. Чорної висвітлено проблеми кримінальної відповідальності за невиконання рішення суду у кримінальному провадженні («Кримінальна відповідальність за невиконання рішення суду у кримінальному провадженні», 2019). Зокрема, дослідницею було здійснено історико-правовий аналіз та здійснено періодизацію розвитку законодавства про кримінальну відповідальність за невиконання рішення суду у кримінальному провадженні. Також О.В. Чорною було обґрунтовано доцільність установлення кримінальної відповідальності за невиконання обмежувальних заходів, обмежувальних приписів або непроходження програми для кривдників як злочину, що посягає на правосуддя в частині невиконання судового рішення. Науковицею були розроблені доктринальні положення про те, що злочин, передбачений ст. 382 КК (в частині кримінального провадження), належить до злочинів із формальним складом, а також про те, що злочини, передбачені статтями 382, 389, 389-1, 390 КК, можуть бути вчинені шляхом як дії, так і бездіяльності. Крім цього, у праці дослідниці набули подальшого розвитку положення щодо критеріїв відмежування злочинів, передбачених статтями 382, 389, 389-1, 390 КК, від суміжних злочинів, кримінальних проступків та адміністративних правопорушень [8, с. 9]. Серед основних проблемних питань, на яких наголошує дослідниця, «недостатня теоретична розробленість проблеми кримінальної відповідальності за невиконання рішень суду у кримінальному провадженні, а також недосконалість статей 3891, 390, 390-1, 391 Кк, i, як наслідок, їх неефективне застосування судами та правоохоронними органами».

У працях В.О. Савченко, С.П. Старосольської, Л.В. Чорнозуб («Кримінальна відповідальність за ухилення від відбування покарання, не пов'язаного з позбавленням волі», 2015) розгляд питань, пов'язаних із невиконанням судового рішення здійснювалось у контексті дослідження кримінальної відповідальності за 
ухилення від відбування покарань, не пов'язаних з обмеженням або позбавленням особою свобод.

Зокрема, В.О. Савченко («Кримінальна відповідальність за ухилення від покарання, не пов'язаного з позбавленням волі», 2017) у контексті невиконання рішення суду досліджено поняття ухилення від покарання, не пов'язаного з позбавленням волі, визначено критерії відмежування ухилення від відбування таких покарань, від суміжних складів злочинів, а також обґрунтовано необхідність законодавчого визначення підстав та правил складання покарань у разі засудження винної особи за ухилення від сплати штрафу, а також підстав заміни штрафу іншими видами покарань за зверненням засудженого [9, с. 7].

Висновки. На підставі викладеного можна дійти висновку про значний ступінь наукової розробки питань невиконання судового рішення у кримінально-правовій науці. Водночас передусім доцільно звернути увагу на те, що переважна кількість зазначених досліджень охоплює кримінально-правову характеристику, проблеми кваліфікації та притягнення до кримінальної відповідальності невиконання судового рішення, що зумовлює зацікавленість саме кримінально-правовою охороною порядку виконання судового рішення як цілісного правового явища. Крім цього, деякі положення, висловлені в юридичній науці, є дискусійними, або такими, що потребують подальшого вивчення з урахуванням плину часу, змінами в законодавстві або у кримінально-правовій політиці держави. Зокрема, насамперед, йдеться про те, які саме злочини належать до тих, які посягають на порядок виконання судового рішення, про предмет злочину, передбаченого ст. 382 КК, а саме про належність до нього тих судових рішень, які не $\epsilon$ предметом примусових виконавчих правовідносин, віднесення окремих діянь, пов'язаних із невиконанням судових рішень, до кримінальних проступків, визначення форми вини у складах злочинів, які посягають на порядок виконання судового рішення. Також у контексті системного характеру проблеми невиконання судових рішень виникають питання щодо умисне недотримання нею висновку Конституційного Суду України обґрунтованості закріплення кримінальної відповідальності за невиконання рішення ЄСПЛ та Конституційного суду, а також умисне недотримання висновку Конституційного Суду України. Подальшої наукової розробки потребує питання виявлення обставин, які б могли бути підставами для звільнення від кримінальної відповідальності за невиконання судового рішення та доцільності закріплення КК такого виду звільнення від кримінальної відповідальності.

\section{Література}

1. Романишин О.Р. Кримінально-правове забезпечення невиконання судового рішення : дис. ... канд. юрид. наук. Львів. 2018. 238 с.

2. Кузнецов В.В. Кримінально-правова охорона: проблеми визначення поняття. Науковий вісник Ужгородського національного університету. Серія: Право. 2015. Вип. 30(2). С. 107-110.

3. Налуцишин В.В. Кримінальна відповідальність за невиконання судового рішення за законодавством України та держав ЄC : дис. ... канд. юрид. наук. Львів. 2019. 219 с.

4. Стратегія реформування судоустрою, судочинства та суміжних правових інститутів на 2015-2020 роки, затвердженої Указом Президента України від 20 травня 2015 року № 276/2015. Режим доступу: https://zakon.rada.gov.ua.

5. Букач М.О. Кримінальна відповідальність за невиконання судового рішення : автореф. дис....канд. юрид. наук. Харків. 2017.18 с.

6. Богонюк Г.І. Кримінально-правова характеристика невиконання судового рішення : дис. на здобуття наук. ступеня канд. юрид. наук. Львів. 2016. 201 с.

7. Головчук В.А. Кримінально-правова охорона порядку виконання судових рішень : дис. на здобуття наук. ступеня канд. юрид. наук. Київ. 2012. 259 с.

8. Чорна О.В. Кримінальна відповідальність за невиконання рішення суду у кримінальному провадженні: автореф. дис. ... канд. юрид. наук. Дніпро. 2019. 27 с.

9. Савченко В.О. Кримінальна відповідальність за ухилення від покарання, не пов'язаного з позбавленням волі : автореф. дис. ... канд. юрид. наук. Київ, 2017. 22 с.

Юсубов К. В., аспірант

Київського університету права Національної академії наук України ORCID: 0000-0001-8209-2006 